\title{
The Determinants of Halal Labeling and Brand Image Towards Purchase Intention and Purchasing Decision
}

\author{
Sutrisno Wibowo ${ }^{1, *}$ Audya el Juhara ${ }^{1}$
}

\author{
${ }^{1}$ Universitas Muhammadiyah Yogyakarta, Indonesia \\ *Corresponding author. Email: wibowo@umy.ac.id
}

\begin{abstract}
This study aims to analyze the influence of halal labeling and brand image on purchase intention and purchasing decisions. This study's object was Wardah's cosmetics. Meanwhile, this study's subject was Wardah cosmetics consumers in Yogyakarta. In this study, a sample of 155 respondents was selected using purposive sampling. The analytical tool utilized in this study was the Structural Equation Modelling (SEM). Based on the analysis results that have been carried out, halal labeling did not significantly influence purchase intention. However, brand image was significant toward purchase intention, halal labeling significantly affected purchasing decisions, and brand image had a significant impact on purchasing decisions.
\end{abstract}

Keywords: Halal Labeling, Brand Image, Purchase Intention, Purchasing Decision

\section{INTRODUCTION}

Islam teaches people always to consume more halal products. There are many benefits derived from using halal products, namely avoiding animal raw materials or other raw materials prohibited by Islamic sharia. As explained in the word of God (Surah Al-Baqarah: 168), "people, eat halal better than that which is on earth." (Surah AL-Maidah: 3) "Forbidden to you (eat) carcasses, blood, pork, (animal flesh) slaughtered in a name other than Allah, who was choked, who was beaten, who fell, who was gored, and who was pounced on by wild animals, except for those whom you had slaughtered, and (forbidden to you) slaughtered for idols". In this sentence, the meaning of the word eating does not only indicate something eaten by mouth, but eating can be interpreted as whatever is consumed and used.

According to the Ministry of Religion, the halal label includes a halal statement on the product packaging to show that the product in question is halal. This phenomenon causes companies to compete in dominating the markets so that they require to install strategies to achieve company goals, ranging from production, pricing, distribution, and promotion strategies. One crucial strategy for a company is a promotion strategy.

According to William [12], a label is part of a product that carries verbal information about the product or seller. A label can be part of the package or label (tag) included in the product. Label, according to government regulation number 69 of 1999, is any statement in the form of pictures, writing, or a combination of both or other forms, which put into, pasted to, or is part of the package.

According to Kotler and Keller [1], images are the way people actually think about them. Furthermore, the brand definition is a name, term, sign, symbol, design, or a combination intended to identify goods or services from one of the sellers or a group of sellers and differentiate them from competitors.

Schiffman and Kanuk [10] argue that purchase intention is a psychological activity because of feelings and thoughts about an item or service desired. Based on the opinion above, purchase intention is someone's desire to purchase an item or service. On the other hand, Peter and Olson [6] state that purchasing decisions are integrity processes carried out to combine knowledge to evaluate two or more alternatives and choose one of them.

\section{THEORETICAL REVIEW}

Intention is a motivation that drives someone to act. Intention arises because of satisfying individual experiences, and when interest has been formed in the individual, it will tend to remain as long as it is an object of objective interest for the individual. According to Schiffman and Kanuk [10], purchase intention is a psychological activity that arises from feelings and thoughts about a desired item or service. Based on the above opinion, purchase intention is someone's desire to purchase goods or services.

According to Kotler and Keller [1], two factors influence a person's purchase intention. First, the attitudes of others have a negative and positive effect on their purchase intention. The negative influence causes consumers to refuse to purchase a product, while the positive influence will motivate consumers to make purchases. Second, uninspired situations are situations that suddenly arise and can change consumers' purchase intention. 


\section{HYPOTHESIS DEVELOPMENT}

\section{The Relationship between Halal Labeling and Purchase Intention}

Research has been conducted by Rambe and Afifuddin [8], which revealed that halal labeling influenced consumer purchase intention. Based on the previous studies' results, the following hypothesis could be derived:

H1: Halal labeling has a positive effect on purchase intention.

\section{The Relationship between Brand Image and Purchase Intention}

Research conducted by Kamilah and Wahyuati [2], Nulufi and Murwartiningsih [3], found that brand image had a positive and significant influence on purchase intention. Based on the previous studies' results, the following hypothesis could be derived:

$\mathrm{H} 2$ : Brand image has a positive effect on purchase intention.

\section{The Relationship between Halal Labeling on Purchasing Decisions}

The results of Sukesti [11], Kamilah and Wahyuati [2] stated that the halal labeling variable positively and significantly affected purchasing decisions. Based on the previous studies' results, the following hypothesis could be derived:

H3: Halal labeling has a positive effect on purchasing decisions.

\section{The Relationship between Brand Image and Purchasing Decisions}

Brand image can influence consumer purchasing decisions about a product brand, meaning that consumers will choose one product brand among other similar brands [3].

The research results carried out by Sallam [9], Kamilah and Wahyuati [2], Oladepo and Abimbola [4], Nulufi and Murwartiningsih [3], Permadi et al. [5], Putra et al. [7] uncovered that brand image positively and significantly influenced purchasing decisions. Based on the previous studies' results, the following hypothesis could be derived:

H4: Brand image has a positive and significant effect on purchasing decisions.

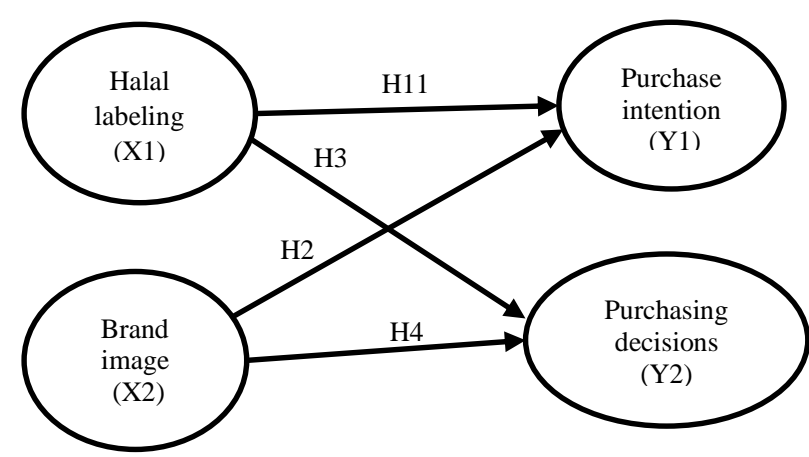

Figure 1.

Research Model

\section{RESEARCH SAMPLES}

Respondents in this study were consumers who used Wardah cosmetics. The sampling technique employed was nonprobability sampling, namely purposive sampling, meaning determining the sample with specific considerations. This study's sample criteria were female consumers in Yogyakarta who used Wardah cosmetics and aged 17 years and over. The number of samples in this study amounted to 155 people.

In this research, the data were obtained by a direct survey method using a questionnaire to get responses from respondents. Each respondent was asked for her opinion through the statements in the questionnaire. In this study, researchers used a Likert scale to measure halal labeling, brand image, purchase intention, and consumer purchasing decisions.

\section{RESULTS TESTING}

The overall model test results had a good fit, which can be seen in Table 1. The goodness of fit test results in this study indicated that the data observed were according to the theory and model.

The results of data analysis and testing of four hypotheses utilizing the Amos program regarding the effect of halal labeling and brand image on purchase intention and purchasing decisions of Wardah cosmetics consumers can be seen in Table 2 .

1. Halal labeling did not have a significant influence on the purchase intention of Wardah cosmetics consumers.

2. Brand image positively and significantly affected the purchase intention of Wardah cosmetics consumers.

3. Halal labeling had a positive and significant effect on the purchasing decisions of Wardah cosmetics consumers.

4. Brand image positively and significantly impacted the purchasing decisions of Wardah cosmetics consumers. 
Table 1. Goodness-of-Fit Test

\begin{tabular}{|l|l|l|l|l|l|l|l|l|}
\hline $\begin{array}{c}\text { Index Goodness- } \\
\text { of-fit }\end{array}$ & Cut of Value & Results & & $\begin{array}{l}\text { Index Goodness- } \\
\text { of-fit }\end{array}$ & $\begin{array}{l}\text { Cut of } \\
\text { Value }\end{array}$ & Results & \\
\hline X2 Chi-Square & Expected small & 160,855 & Not fit & & AGFI & $\geq 0,90$ & 0,851 & Not fit \\
\hline Probability & $\geq 0,05$ & 0,000 & Not fit & & TLI & $\geq 0,90$ & 0,906 & Fit \\
\hline CMIN/DF & $\leq 2,00$ & 1,625 & Fit & & CFI & $\geq 0,90$ & 0,922 & Fit \\
\hline GFI & $\geq 0,90$ & 0,892 & Not fit & & RMSEA & $\leq 0,08$ & 0,064 & Fit \\
\hline
\end{tabular}

Table 2. Hypothesis testing

\begin{tabular}{|c|l|c|c|c|c|c|}
\hline No & Hypothesis & Estimate & S.E. & C.R. & P & \\
\hline 1. & $\begin{array}{l}\text { Halal labeling has a positive and significant effect on the } \\
\text { purchase intention of Wardah cosmetics consumers. }\end{array}$ & 0,073 & 0,076 & 0,957 & 0,338 & $\begin{array}{c}\text { Not } \\
\text { Supported }\end{array}$ \\
\hline 2. & $\begin{array}{l}\text { Brand image has a positive and significant influence on the } \\
\text { purchase intention of Wardah cosmetics consumers. }\end{array}$ & 0,810 & 0,123 & 6,601 & $* * *$ & Supported \\
\hline 3. & $\begin{array}{l}\text { Halal labeling has a positive and significant effect on the } \\
\text { consumers' decision to purchase Wardah cosmetics. }\end{array}$ & 0,158 & 0,066 & 2,390 & 0,017 & Supported \\
\hline 4. & $\begin{array}{l}\text { Brand image has a positive and significant effect on the } \\
\text { consumers' decision to purchase Wardah cosmetics. }\end{array}$ & 0,806 & 0,127 & 6,331 & $* * *$ & Supported \\
\hline
\end{tabular}

\section{CONCLUSIONS}

Based on the results of data analysis and testing of the four hypotheses using the Amos program regarding the effect of halal labeling and brand image on purchase intention and purchasing decisions of Wardah cosmetics, the research concludes

1. Halal labeling does not have a significant influence on the purchase intention of Wardah cosmetics consumers.

2. Brand image have a positive and significant influence on the purchase intention of Wardah cosmetics consumers.

3. Halal labeling have a positive and significant influence on purchasing decisions of Wardah cosmetics consumers.

4. Brand image have a positive and significant influence on purchasing decisions of Wardah cosmetics consumers.

\section{REFERENCES}

[1] Kotler, Philip, and Kevin Lane Keller. 2016. Marketing Management. Global Edition.Pearson Education.

[2] Kamilah, G., \& Wahyuati, A. (2017). The Effect of Halal Labeling and Brand Image on Purchasing Decisions Through Purchasing Interest. Journal of Management Science \& Research, 6 (2).

[3] Nulufi, K, \& Murwartiningsih. 2015. Purchasing Interest as a Mediator the Effect of Brand Image and Consumer Attitudes Towards Batik Purchasing Decisions in Pekalongan. Management Analysis Journal, 4 (2).
[4] Oladepo, O. I and Odunlami S. A. 2015. The Influence of Brand Image and Promotional Mix on Consumer Buying Decision, A Study Of Beverage Consumers In Lagos State, Nigeria. British Journal of Marketing Studies, 3 (4).

[5] Permadi, P. C. (2014). The Effect of Brand Image on Word of Mouth and Purchasing Decisions (Survey on Consumer Dapoer Mie Galau Jalan Selorejo 83 Malang). Journal of Business Administration, 10 (1).

[6] Peter, J Paul and Jerry Olson. 2014. Consumer Behavior and Marketing Strategies. Translated by Diah Tantri Dwiandani, Ninth Edition, Volume 1. Jakarta: Salemba Empat.

[7] Putra, S., \& Bimo, G. (2015). Influence of Company Image on Visiting Interests and Visiting Decisions (Survey on Visitors Park Recreation Pt. Selecta, Batu City, East Java). Journal of Business Administration, 26 (2).

[8] Rambe, Y. M., \& Afifuddin, S. (2012). The Effect of Inclusion of Halal Labels on Instant Noodle Packaging Against Interest in Purchasing Muslim Communities (Case Study on Al-Washliyah University Students, Medan). Economics and Finance, 1 (1).

[9] Sallam, M. A. (2014). The effects of brand image and brand identification on brand love and purchase decision making: the role of WOM. International Business Research, 7 (10), 187.

[10] Schiffman, Leon and Kanuk, Leslie. 2007. Consumer Behavior. Seventh Edition. Jakarta: PT. Index.

[11] Sukesti, F \& Mamdukh B. 2014. The Halal Influence of Labels and Personal Religion on Purchase Decision on Food Products In Indonesia. International Journal of Business, Economics, and Law, (7).

[12] William, J. S. 2004. Principles of Marketing. Erlangga Jakarta. 